\title{
Fascism as a Mass-Movement: Translator's Introduction
}

\author{
Jairus Banaji \\ Department of Development Studies, \\ School of Oriental and African Studies, University of London \\ jairus_b@hotmail.com
}

\begin{abstract}
This Introduction to Rosenberg's essay starts with a brief synopsis of his life, then summarises the key arguments of the essay itself before looking briefly at the twin issues of the social base of the fascist parties (wider than just the 'petty bourgeoisie') and the passive complicity/compliance of 'ordinary Germans', as the literature now terms whole sectors of the civilian population that were defined by their apathy or moral indifference to the horrors of the Nazi state.
\end{abstract}

\section{Keywords}

Arthur Rosenberg, Marxist theories of fascism, white-collar workers, mass-complicity

Arthur Rosenberg was a major historian and Communist Reichstag deputy best known for his books The Birth of the German Republic, 1871-1918 (1928) and A History of Bolshevism (1932). The three broad phases of his life as a Marxist are the years from 1919 to April 1927, when he played an active part in the KPDLeft, the period from May 1927 to March 1933, following his resignation from the KPD (the years that best define him as a 'Communist without a party'), and the tragic final decade of his life when he fled Germany along with his family, would find himself stripped of German citizenship, and lead an impoverished life as a tutor in Brooklyn College, New York, having failed to find any sort of academic position in England. All of Rosenberg's major works stem from the last period of his life, except for The Birth of the German Republic, which he published in 1928.

As a member of the left wing of the USPD, Rosenberg found himself joining the German Communist Party in October 1920. The hallmark of the Left-current within the KPD was of course its intransigent opposition to any sort of front with the SPD in the intensely volatile political climate of Weimar, but unlike Fischer and Maslow (more substantial leaders of the 'Berlin Left', as the 
KPD-Left was called), Rosenberg himself was deeply resentful of excessive Comintern interference in the affairs of the German party. By 1925 the KPDLeft was split wide open, lost control of the party-leadership to Thälmann, and saw a major purge of the Left-elements, including Korsch and Werner Scholem, all denounced as 'anti-Bolshevik'. Rosenberg seems to have survived this purge but resigned from the party in April 1927. He remained a Reichstag deputy for about a year, but was doubly ostracised both within the academic establishment and by the orthodox Left in Germany. Thanks to the implacable hostility of Eduard Meyer and Ulrich Wilcken, he was denied a proper appointment in Berlin University. By now, the eve of the massive expansion of Nazism among the electorate, he wrote exclusively for publications run by the SPD. In $A$ History of Bolshevism, the last book he published before his exile, he characterised Stalin's Russia as 'state-capitalist' (this in 1932). On 30 January 1933, Hindenburg appointed Hitler Chancellor and the German Communists frantically appealed to the SPD for a 'united front' when the terror started in February. By the end of March Rosenberg had fled to Zurich with his family, in September he moved to London where he failed to land a job at the LSE, and then four months later got a one-year fellowship at the University of Liverpool where he wrote Democracy and Socialism. Fascism as a Mass-Movement appeared as a booklet ('Broschüre') in 1934 under the pseudonym 'Historikus' and published by the Karlsbad publisher Graphia, which was run by SPD refugees and German-speaking Social Democrats in Czechoslovakia. Rosenberg left for the States in late October 1937 and eventually died of cancer in $1943{ }^{1}$

The abbreviated version of Rosenberg's fascism-essay that runs to $65^{\text {-odd }}$ pages in Abendroth's collection Faschismus und Kapitalismus is the one translated here. ${ }^{2}$ It divides into three portions, the first mapping a general vision of the history and politics of Europe in the later-nineteenth century, and the second and third dealing with Italy and Germany respectively. The distinctive feature of the argument is summed up in the title itself, namely, the conception of fascism as a mass-movement. Written in 1933, this contrasted both with the Comintern's official line that fascism was 'the power of financecapital itself', ${ }^{3}$ a sort of political incarnation of capital, and with the contrary theories that saw fascism mediating between capital and labour on the model

1. Biographical data from Riberi 2001 and Keßler 2003, both of which (Keßler especially) have full bibliographies of Rosenberg's writings. Eduard Meyer was Germany's leading ancient historian at the time but also a staunch nationalist (a supporter of the Deutsche Vaterlandspartei) and a resolute opponent of Weimar, e.g., Keßler 2003, pp. 48-9.

2. Rosenberg 1967.

3. Dimitroff told the Seventh Congress of the Comintern: 'Der Faschismus - das ist die Macht des Finanzkapitals selbst'. 
implied in Marx's analysis of Bonapartism. ${ }^{4}$ Rosenberg seems to have steered clear of this whole debate, which as a historian he may well have found superficial. The crucial point for him was to know where fascism came from, not what it resembled in the past. He rejected the view that fascism was somehow primordially or quintessentially connected with the petty bourgeoisie in particular - either driven by it or largely founded on it - suggesting that it had a much wider social appeal and was more widely based than that view implied. If fascism was a product of its own ideology, then that ideology was already widespread by 1914. Throughout the main countries of Europe, liberalism was either stillborn or successfully contained and defeated. This was as true of the Hapsburgs as it was of Germany or Britain for that matter. The crux of the new 'authoritarian conservatism', as he called it, was its ability to win mass-support, popular conservative majorities, by encouraging a new breed of nationalism that was ultra-patriotic, racist and violently opposed to the Left. This took different forms in different parts of Europe but its essential features were the same - a 'demagogic nationalism' that targeted minorities (in Europe, mainly Jews) to build a mass-support. The powerful surge of antisemitism that swept through Europe in the last quarter of the nineteenth century was a fundamental part of this radical nationalism.

Thus Rosenberg's key argument here is that 'the ideology which is today called "fascist" was already fairly widespread throughout Europe before the War, and exerted a strong influence on the masses.' He goes on to say, 'However, with one exception, what was missing then was the peculiar tactic of using stormtroopers which is thoroughly characteristic of modern fascism. The sole exception was formed by the Black Hundreds of Tsarist Russia and their ability to stage pogroms' (p. 152).

Legally, the stormtroopers should be tried and sentenced to jail. But in fact nothing of the sort happens to them. Their conviction in the courts is pure show - either they do not serve their sentence, or they are soon pardoned. (p. 153.)

The important insight here is that stormtroopers work with the connivance of the state, a theme he returns to repeatedly. As for the pogrom itself, he claims 'the rage of the patriotic masses has to be manufactured' (ibid.). This is what happened in the Tsarist pogroms of 1905.

Rosenberg saw Italian fascism as a modernising force that broke the power of the Southern cliques to pave the way for Northern industrial capitalism. In Italy, 'Fascism was and remained the party of the advanced North' (p. 169), smashing the working class but also 'br[eaking] the dominance of the backward

4. Notably Thalheimer 1967 (from Gegen den Strom. Organ der KPD (Opposition), 1930). 
feudal cliques of Central and Southern Italy' (ibid.). 'Mussolini was the leader of the modern Italian North, with its bourgeoisie and its intelligentsia.' (ibid.)

The state-capitalist concentration of the country in the so-called 'corporatist system' facilitated control of the country by the most efficient groups of capitalists. Heavy industry, chemicals, automobiles, aircraft, and shipping were all systematically developed. Where in all this is the 'petty-bourgeois' spirit that is supposed to form the essence of fascism? (p. 17o.)

In the German case, it is the sheer weight of the nationalist Right that is so striking. Nazism emerged from this background, survived its fragmentation in the years of stability between 1924 and 1929, and retotalised both its ideologies as well as much of the German past - the massive weight of militarism and the widespread latent antisemitism that survived into the Weimar period. Rosenberg starts the German analysis by drawing a key distinction between households dependent on wage-employment [die Arbeitnehmerschaft] and industrial workers in the narrower sense. For example, he included governmentemployees and office-workers in the proletarian camp because their jobs involved some form of paid employment. Of a total of around 25 million paid employees and proletarians in this broad sense, 'at most only 11 million were factory-workers in the true sense' (p. 172). Those workers, say, roughly a third of Germany's population, remained loyal to the Left down to the bitter end, ${ }^{5}$ but other sections of the general mass of paid employees (the majority) consistently voted for the bourgeois parties throughout the Weimar years. The huge Republican majority of January 1919 soon crumbled. The November Revolution left the state-machinery intact - that is, in the hands of the old bureaucracy, a bastion of reaction - and the middle-class, 'large sections of the white-collar and government-employees who had greeted the Republic in November with enthusiasm', 'would soon stand aloof from it in sheer disappointment' (p.173). In fact, the percentage of the wage-earning population that was opposed to the Left (including the Catholic Centre Party) increased dramatically in the crucial early years of Weimar. Rosenberg claims that by March 1933, when the Nazis polled a stunning 17 million votes against 12 million for the Social Democrats and KPD, something like $11 \frac{11 / 2}{2}$ million votes of the 'other wage-earners'-category went to the parties of the Right.

Fascism as a Mass Movement is an essay about the origins and growth of fascism, not fascism in power. Though much of the humongous bibliography that has grown up around the subject particularly since the late sixties deals

5. The KPD was a solidly working-class party, cf. Kater 1983, p. 37: '[in 1927] more than 80 percent of the KPD members belonged to the working class'. 
overwhelmingly with the latter (with Neumann's Behemoth as an early and outstanding example of the kind of issues that would dominate subsequent historiography), the essential themes of Rosenberg's argument stand fully vindicated by recent scholarship. 'The error of the Italian Communist Party lies mainly in the fact that it sees fascism only as a military-terrorist movement, not as a mass movement with deep social roots', Clara Zetkin warned in $1923 .{ }^{6}$ It is this conception - of the capacity of the Right to mobilise mass-support - that forms the central thread of Rosenberg's essay, where the key to its interpretation lies both in the political defeat of liberalism and its rapid retreat across most of Europe in the nineteenth century and in the virulent nationalisms that emerged to buttress the rule of traditional élites against the threat of democracy and Marxist socialism. If the singular brutality of the Nazi genocide remains a watershed in the history of the modern world, ${ }^{7}$ one that Rosenberg could scarcely have anticipated in 1933, the racial myth of the Volksgemeinschaft that paved the way for it was far from novel, its roots firmly embedded in the 'integral nationalism' of Treitschke and Maurras and the visions of national redemption preached by Schönerer and Lueger (against both Slavs and Jews) to pan-German constituencies in Austria that Weiss has described as 'one of the most anti-Semitic publics west of Russia'. ${ }^{8}$ Thus the argument, cited above, that "the ideology which is today called "fascist" was already fairly widespread throughout Europe before the War' is thoroughly convincing. It is a major insight into why the fascist movements could expand so rapidly, both in Italy and in Germany (in the early and late twenties respectively), against the background of war-hysteria and assaults on the Left (in Italy) and of a powerful nationalist Right in Germany that prepared the ground for the Nazis. The centrality of racism to Nazism in particular emerges more forcefully in Rosenberg's essay than any other Marxist writing of the twenties and early thirties. So does the argument that the success of the fascists depended crucially on the connivance or active complicity of the existing state-authorities, many of whom would of course have been active members of the PNF and NSDAP. This was starkly obvious in Italy where the squadristi 'succeeded because they could always count on the state', (p. 164) but no less so in Germany where, as Neumann noted, not one of the conspirators in the right-wing Kapp Putsch of 1920 had been punished even 15 months later, 'the Weimar criminal courts were part and parcel of the anti-democratic camp', and the 'courts invariably

6. Zetkin cited in Poulantzas 1974, p. 84 . She refers to 'broad social layers, large masses that reach even into the proletariat', cf. Riddell 2011.

7. Traverso 1999.

8. Weiss 1977, p. 119, with Chapter 6 on Heinrich von Treitschke, and Chapter 8 on Maurras. 
became sounding-boards for [Nazi] propaganda'; 9 and where, as Rosenberg points out, 'a whole series of government-officials, especially in the army,... maintained close contact with theFreikorps and [other] counter-revolutionaries' (p. 176). Finally, a major part of the essay sets out to discredit the so-called 'middle-class theory' of fascism. Rosenberg was convinced that fascism was not a petty-bourgeois movement nor was the mass-base of the fascist parties confined to the petty bourgeoisie. Of course, Trotsky saw fascism 'raising itself to power on the backs of the petty bourgeoisie', and then putting the middleclasses 'at the service of capital'. 'Through the fascist agency, capitalism sets in motion the masses of the crazed petty bourgeoisie. ${ }^{10}$ Reich, too, made the middle-class central to fascism, seeing submission to or 'identification with' 'authority, firm, state, nation, etc.' as peculiar to the mass-psychology of the lower-middle-class. 'The middle class was and continued to be the mainstay of the swastika.'11 But of course none of these characterisations prove that fascism was a movement of the middle-classes, at least in the stronger sense in which Luigi Salvatorelli had argued this for Italy in $1923 .{ }^{12}$

What is true, on the other hand, is that the middle-class was particularly susceptible to Nazi propaganda, and that, whereas 'working-class milieus dominated by the parties of the Left... remained unyielding terrain for the NSDAP', a major share of the Nazi vote in the electoral landslide of September 1930, at least 40 per cent, came from the middle-classes. ${ }^{13}$ That a further 25 per cent of Nazi voters was drawn from the working class suggests first that the German workers were far from homogeneous either socially or politically, and second that the appeal of fascism was not class-specific but rather, as Neumann suggested, more widely spread over 'the most diverse social strata'. ${ }^{14}$ These are both points that come through with remarkable clarity in Fascism as a MassMovement. Rosenberg's distinction between the general mass of wage-earners/ salaried employees and industrial workers in particular crucially explains the difference in political behaviour between workers who stayed with the Left down to the end and workers who supported the Nazis. Kershaw notes that,

9. Neumann 1942, pp. 27ff., and his striking observation that '[i]n the centre of the counterrevolution stood the judiciary'.

10. Trotsky 1971, pp. 405, 406, 155 .

11. Reich 1972, pp. 4off., and the statement 'fascism, viewed with respect to its mass basis, was actually a middle-class movement' (Reich 1972, p. 42).

12. Salvatorelli 1923 .

13. Kershaw 2001, p. 334 .

14. Neumann 1942, p. 37: the NSDAP was 'composed of the most diverse social strata but never hesitat[ed] to take in the dregs of every section, supported by the army, the judiciary, and parts of the civil service, financed by industry, utilizing the anti-capitalist sentiments of the masses and yet careful never to estrange the influential moneyed groups'. 
down to the Reichstag election of May 1928, the Nazis' 'concentration on the industrial working class had not paid dividends', ${ }^{15}$ yet Mühlberger, analysing branch-membership data for various periods between 1925 and 1933, claims that the Nazis secured 'significant support' in predominantly lower-class areas. ${ }^{16}$ Anywhere between 28 per cent and 46 per cent of Nazi branch-members might consist of workers, both skilled and unskilled. ${ }^{17}$ The contradiction is only apparent. First, the 'rush to the swastika' occurred chiefly after 1928, following the winter of 1928-9 and against the background of worsening economic conditions. But, just as important, if workers living in heavily industrialised urban centres such as Hamburg remained immune to Nazism, those who lived in small communities and villages were more vulnerable. 'It was residence in a rural environment that was decisive.'18 And not just residence, of course, but age, gender, religion, and whether one retained a job at all. Workers were on the whole significantly under-represented in the hard-core Nazi ranks, except for the SA where, at least in Western and Southern Germany, the rankand-file was largely 'lower class'19 (mainly unemployed, as Rosenberg notes), the white-collar groups, or 'new middle-class' more broadly, dramatically overrepresented, as were 'the élite', including students and academic professionals. Certainly the most balanced assessment of this still largely controversial issue remains the one Noakes offered years ago in his study of Lower Saxony and electoral districts that saw some of the highest Nazi votes in 1930-3. He concluded that the Nazis 'could appeal to a whole range of classes and interests', even if 'it was the lower middle class which was most attracted to the party'. ${ }^{20}$ This, broadly, is Rosenberg's position, since he makes repeated reference to the white-collar element and civil servants being a decisive part of the Nazi social base, while refusing to characterise either the party or the movement as middle-class. White-collar workers in particular showed a bizarre affinity for the racist [völkisch] organisations that were striking precursors of the Nazi movement, above all the Deutscher Schutz- und Trutzbund (DSTB) and its successor the DVSTB. ${ }^{21}$ That the SPD white-collar union failed to organise more than a handful of these employees who preferred to join 'professional'

15. Kershaw 2001, p. 303.

16. Mühlberger 1991, p. 203 .

17. Mühlberger 1991, pp. 37, 77, 115, 139 .

18. Kater 1983 , p. 36 .

19. Mühlberger 1991, p. 180. 'Workers' formed $5^{8}$ per cent of all SA recruits prior to 1933 (Mühlberger 1991, p. 177).

20. Noakes 1971, pp. 79, 19.

21. Noakes 1971, pp. 9-11; Merkl 1975, p. 56. Lohalm 1970 calls the Bund a 'Wegbereiter des Nationalsozialismus'. 
organisations $^{22}$ suggests that, more than material interest or the immediate perception of one, these (white-collar elements, lower- and middle-ranking civil servants, the self-employed, etc.) were strata of the Mittelstand that drew their identity or their sense of one from their family-backgrounds and the deeply nationalist and authoritarian traditions interiorised there. ${ }^{23}$ Describing his own experience of visiting large factories and managements in 1934 and 1935, Sohn-Rethel wrote:

\begin{abstract}
As a rule the hard core of the workers, but to a lesser extent the younger ones and the new apprentices, were not Nazi and did not pretend to be Nazi... But the middle and lower white-collar workers [Angestellten] were those for whom the party-badge was a symbol of faith and who assumed unmistakeable Nazi bearings... The members of the 'new intelligentsia' were the most inflexible of these - the real rabid fanatics [who] seemed so passionately committed to the interests of capital without having any personal share in its profits. ${ }^{24}$
\end{abstract}

'Symbol of faith', 'rabid fanatics' - these are not characterisations that could apply to the mass of 'ordinary Germans', those who were neither direct perpetrators nor hate-campaigners. Yet this is where the real problem of fascism lies. As Christopher Browning notes in his extraordinary book Ordinary Men, 'the vast majority of the general population did not clamor or press for anti-Semitic measures', yet they allowed a gulf to open up between the Jewish minority (and of course other minorities) and themselves. ${ }^{25}$ Thus we have a paradox or seeming paradox of what Browning in another work calls a 'widespread receptivity to mass murder', ${ }^{26}$ or what, less dramatically, has been called 'German public support for Nazi rule', ${ }^{27}$ including the fact that knowledge of the concentration-camps (and deportations, mass-shootings of Jews, etc.) was available and 'fairly widespread', ${ }^{28}$ coupled, on the other hand, with the sharp and obvious distinction between the overtly Nazi element of the population and a civilian population, the so-called 'Mitläufer', that could show repeated disgust at overt acts of brutality and violence even as it accepted 'the broad principles of legal discrimination and exclusion on racial grounds' and harboured discriminatory attitudes. ${ }^{29}$ Brecht's own ambivalence about

\footnotetext{
22. Lebovics 1969, p. 37 .

23. Merkl 1975, based on the Abel biographies.

24. Sohn-Rethel 1975, pp. 195-6; Sohn-Rethel 1978, pp. 135-7, translation modified.

25. Browning 2001, p. 200.

26. Browning 1992, p. 64.

27. Bull (ed.) 1986, p. 5. Of course, as Tim Mason never failed to point out, ' $[\mathrm{t}]$ he Nazi regime set out to obliterate the German Left', arresting anywhere between a hundred to two hundredthousand socialists and murdering 'tens of thousands' of them; Mason 1986, pp. 96-7.

28. Kershaw 1986, pp. $378 \mathrm{ff}$.

29. Kershaw 1986.
} 
the distinction between the German people and the National Socialists would of course survive to dominate postwar Germany and appear repeatedly in Fassbinder's work and in films such as Germany, Pale Mother. As Anton Kaes says, 'Those born in 1945, like Fassbinder, were given the German past as an unwanted legacy'. ${ }^{30}$ Fassbinder himself had an acute sense of the continuities between the bourgeois values of the nineteenth century and the ideology of the Third Reich, the ferocious culmination of German/bourgeois nationalism in the horrors of the Nazi state. ${ }^{31}$ This is a perspective close to Rosenberg's view that it was the bourgeoisie that formed the chief bearer of this redemptive conception of German power in the decades before 1914 (pp. 188-9). But the problem of civilian compliance remains. 'O Germany, pale mother! / What have your sons done to you...' The Nazi movement was almost exclusively male, ${ }^{32}$ yet millions of women voted for the Nazis in 1932, and in 1936 'eleven million out of thirty-five million women in Germany were members of the NS-Frauenschaft'. ${ }^{33}$ To suppose that women were 'peculiarly resistant to National Socialism' 34 is to espouse a strangely essentialist feminism that fails to confront the issue of fascism in any serious way, and just as David Bankier's work broke new ground in exploring the issue of compliance head-on, showing the complex ways in which passive and genocidal forms of racism interacted, ${ }^{35}$ Claudia Koonz's books Mothers in the Fatherland and The Nazi Conscience are both important pointers to some of the ways in which socialists and the Marxist Left should restructure the terms of the debate about fascism, neither exaggerating the extent to which workers (for example) were integrated into the fascist state ${ }^{36}$ nor shying away from the harder issue of the type and degree of complicity of large masses of the population in the régime's criminality, however we choose to characterise that - as 'genocidal consensus', ${ }^{37}$ 'passive complicity', ${ }^{38}$ or just plain 'moral indifference'. ${ }^{39}$

\footnotetext{
30. Kaes 1992, p. 76.

31. Fassbinder 1992, pp. $115 \mathrm{ff}$.

32. Mühlberger 1991, p. 90: 'It was almost exclusively a male movement...'

33. Saldern 1996, pp. 219, 217.

34. Stephenson 1981, cited in Saldern 1996, p. 218.

35. Bankier 1992.

36. See, for example, the excellent paper by Tobias Abse (Abse 1996), which argues that 'a tradition of class-conscious militancy established in Italy in particular pre-Fascist circumstances was not broken under Fascism' (Abse 1996, p. 53) and that Italian Fascism 'never really gained any widespread consensus of support amongst the industrial working class of northern and central Italy' (Abse 1996, p. 42).

37. Koonz 2003, p. 221.

38. Kulka and Rodrigue 1984.

39. Kershaw 1986, discussing his own earlier assessments in Popular Opinion and Political Dissent in the Third Reich (1983).
} 
Finally, even if fascism today is not and will not be the return of old-style fascism but more eclectic and variegated versions of extreme-Right politics, Rosenberg's essay loses none of its relevance for us. In particular, the increasing support drawn from the working class by parties of the extreme Right in countries such as France, Austria, Denmark and Norway, ${ }^{40}$ or the ability of the Sangh Parivar in India (the RSS/BJP combine) to create mass-mobilisations based on hate-campaigns and strategies of tension should be some of the more pressing reasons why the Left needs to return to the issue of fascism in a central way.

\section{References}

Abendroth, Wolfgang 1967, Faschismus und Kapitalismus. Theorien über die sozialen Ursprünge und die Funktion des Faschismus, Frankfurt: Europäische Verlagsanstalt.

Abse, Tobias 1996, 'Italian Workers and Italian Fascism', in Fascist Italy and Nazi Germany: Comparisons and Contrasts, edited by Richard Bessel, Cambridge: Cambridge University Press.

Bankier, David 1992, The Germans and the Final Solution: Public Opinion under Nazism, Oxford: Blackwell.

Browning, Christopher R. 1992, The Path to Genocide: Essays on Launching the Final Solution, Cambridge: Cambridge University Press.

2001, Ordinary Men: Reserve Police Battalion 101 and the Final Solution in Poland, Harmondsworth: Penguin Books.

Bull, Hedley (ed.) 1986, The Challenge of the Third Reich: The Adam von Trott Memorial Lectures, Oxford: Clarendon Press.

Fassbinder, Rainer Werner 1992, The Anarchy of the Imagination: Interviews, Essays, Notes, edited by Michael Töteberg and Leo A. Lensing, translated by Krishna Winston, Baltimore: The Johns Hopkins University Press.

Hainsworth, Paul 2008, The Extreme Right in Western Europe, Abingdon: Routledge.

Kaes, Anton 1992, From Hitler to Heimat: The Return of History as Film, Cambridge, MA.: Harvard University Press.

Kater, Michael H. 1983, The Nazi Party: A Social Profile of Members and Leaders 1919-1945, Oxford: Blackwell.

Kershaw, Ian 1986, 'German Popular Opinion and the “Jewish Question”, 1939-1943: Some Further Reflections', in The Jews in Nazi Germany 1933-1943, edited by Arnold Paucker, Sylvia Gilchrist and Barbara Suchy, Tübingen: Mohr.

— 2001, Hitler 1889-1936: Hubris, Harmondsworth: Penguin Books.

Keßler, Mario 2003, Arthur Rosenberg. Ein Historiker im Zeitalter der Katastrophen (1889-1943), Cologne/Weimar/Vienna: Böhlau Verlag.

Koonz, Claudia 1988, Mothers in the Fatherland: Women, the Family and Nazi Politics, London: Methuen.

2003, The Nazi Conscience, Cambridge, MA.: Harvard University Press.

Kulka, Otto Dov and Aron Rodrigue 1984, 'The German Population and the Jews in the Third Reich', Yad Vashem Studies, 16: 421-35.

40. Hainsworth 2008, pp. $95 \mathrm{ff}$. 
Lebovics, Herman 1969, Social Conservatism and the Middle Classes in Germany 1914-1933, Princeton: Princeton University Press.

Lohalm, Uwe 1970, Völkischer Radikalismus. Die Geschichte des Deutschvölkischen Schutz- und Trutz-Bundes 1919-1923, Hamburg: Leibniz Verlag.

Mason, Tim 1986, 'The Third Reich and the German Left', in Bull (ed.) 1986.

Merkl, Peter H. 1975, Political Violence under the Swastika: 581 Early Nazis, Princeton: Princeton University Press.

Mühlberger, Detlef 1991, Hitler's Followers: Studies in the Sociology of the Nazi Movement, London: Routledge.

Neumann, Franz 1942, Behemoth: The Structure and Practice of National Socialism, London: Victor Gollancz.

Noakes, Jeremy 1971, The Nazi Party in Lower Saxony, 1921-1933, Oxford: Oxford University Press.

Poulantzas, Nicos 1974, Fascism and Dictatorship: The Third International and the Problem of Fascism, translated by Judith White, London: New Left Books.

Reich, Wilhelm 1972 [1933], The Mass Psychology of Fascism, translated by Vincent R. Carfagno, London: Souvenir Press.

Riberi, Lorenzo 2001, Arthur Rosenberg. Democrazia e socialismo tra storia e politica, Milan: FrancoAngeli.

Riddell, John 2011, 'Clara Zetkin's Struggle for the United Front', available at: <http://johnriddell .wordpress.com/2011/05/03/clara-zetkin $\% \mathrm{E}_{2} \% 80 \% 99$ s-struggle-for-the-united-front/>.

Rosenberg, Arthur 1934 [1932], A History Of Bolshevism: From Marx to the First Five Years' Plan, translated by Ian F.D. Morrow, Oxford: Oxford University Press. 1962 [1928], The Birth of the German Republic, 1871-1918, translated by Ian F.D. Morrow, New York: Russell and Russell.

1967, 'Der Faschismus als Massenbewegung. Sein Aufstieg und seine Zersetzung', in Abendroth (ed.) 1967 .

Saldern, Adelheid von 1996, 'Victims or Perpetrators? Controversies about the Role of Women in the Nazi State', in Fascist Italy and Nazi Germany: Comparisons and Contrasts, edited by Richard Bessel, Cambridge: Cambridge University Press.

Salvatorelli, Luigi 1923, Nazionalfascismo, Turin: P. Gobetti.

Sohn-Rethel, Alfred 1975, Ökonomie und Klassenstruktur des deutschen Faschismus. Aufzeichnungen und Analysen, Second Edition, Frankfurt: Suhrkamp Verlag.

— 1978, Economy and Class Structure of German Fascism, translated by Martin Sohn-Rethel, London: CSE Books.

Stephenson, Jill 1981, The Nazi Organisation of Women, New York: Barnes and Noble.

Thalheimer, August 1967, 'Über den Faschismus', in Abendroth (ed.) 1967.

Trotsky, Leon 1971, The Struggle Against Fascism in Germany, New York: Pathfinder Press.

Weiss, John 1977, Conservatism in Europe 1770-1945: Traditionalism, Reaction and CounterRevolution, London: Thames and Hudson. 